\title{
Malaysia's International Relations and Foreign Direct Investment (FDI): A Structural Change Analysis
}

\author{
Har Wai Mun \\ Faculty of Accountancy and Management, Universiti Tunku Abdul Rahman \\ Bandar Sungai Long, 43000 Selangor, MALAYSIA \\ E-mail: harwm@mail.utar.edu.my
}

Lam Zheng Ling

Faculty of Accountancy and Management

Universiti Tunku Abdul Rahman, MALAYSIA

Chan Mew Leng

Faculty of Accountancy and Management

Universiti Tunku Abdul Rahman, MALAYSIA

Liew Khai Yi

Faculty of Accountancy and Management

Universiti Tunku Abdul Rahman, MALAYSIA

Har Ee Ling

Faculty of Accountancy and Management

Universiti Tunku Abdul Rahman, MALAYSIA

Lum Carmen

Faculty of Accountancy and Management

Universiti Tunku Abdul Rahman, MALAYSIA

\begin{abstract}
This study aims to identify the effect of international relations and the presence of structural change using Analysis of Covariance (ANCOVA) and Chow test respectively. It also aims to examine the long run relationships among Malaysia's GDP and inward FDI, as well as among Malaysia's total FDI and inward FDI taking into consideration of international relations using Engle-Granger test. Furthermore, Error Correction Mechanism (ECM) is used to examine whether the variables are converge in the lng run. This study supports that international relation affects inwards FDI from all selected countries (Japan, United States, Singapore and Germany). In addition, inwards FDI from respective countries have long run relationship with Malaysia's GDP and Malaysia's total FDI. It also found that the respective variables are converging in the long run. With this finding in mind, international relations-focused policies can be created in order to boost up Malaysia's FDI inwards and growth.
\end{abstract}

Keywords: International relations, Guanxi, FDI, GDP, Malaysia, Structural change analysis 


\section{Introduction}

Ancient Eastern war strategists believed in existence of "hidden resources" that can be of great use in war fare. For example, Sun Tzu has a full chapter each on the use of two "hidden resources", which are "terrain" and "fire" in his "Art of War". Kongming (also known as Zhuge Liang, a renowned Chinese ancient war strategist who was the Chancellor of Shu Kingdom during the era of "three kingdom") recognized the existence of two kinds of forces. One kind is visible soldiers armed with weapons. The other kind is invisible soldiers, which he referred to all sorts of nature such as the sun, the moon, the stars, the wind, the clouds, water, fire, thunder and lightning, mountains and rivers. In modern economic context, there are "hidden resources" too. International relations is believed to be one of them, which could have great impact to economic but unfortunately, often overlooked. International relations have usually been assumed (ignored) as an endogenous variable in various economic modeling, in which its effect would not explicitly being captured by the model.

Malaysia is a multi-racial society comprises of many ethnic groups, mainly Malay, Chinese and Indian. As Malays are predominantly Muslim, establishment of an "Ummah network" as proposed by Har, Lam \& Liew (2009) may enhance FDI inflow between Islamic countries. Malaysia's historical background as former colonial of British and its contemporary international association with Commonwealth, regional blocks like ASEAN and various other international bodies provide ample "hidden resources" in the form of international relations. Hence, this adds to the significant of this study. Example of effort based on international relations is the Look East policy (LEP) introduced in the beginning of the 1980s by the then Malaysia Prime Minister Mahathir bin Mohammad to encourage a closer look at work ethics, management styles and values of successful East Asian economies, such as South Korea and Japan (Furuoka, Lo \& Kato, 2008).

In year 2004, foreign direct investment (FDI) also faced significant decline due to competitions form lower cost manufacturing countries. Delay in application processing, slow decision making by local authorities and absentness of a one-stop centre for businessman sums up to the time-consuming bureaucracy in Malaysia. Year 2005 significantly shows that Malaysia's FDI has shrunk to a miserable state. National Economic Action Council (NEAC) group member Zainal Aznam Yusof also stated his regret that Malaysia has started losing its competitive edge (Lim, 2006). FDI for the first quarter of 2009 has only been 4.2 billion ringgit compared to 46 billion ringgit in 2008 (Malaysia Daily News, 2009). Hence, the study of possibility of utilizing international guanxi to attract FDI to Malaysia (or any other developing countries) becomes more important.

International relations are believed to be able to act as "helping hand" to foster FDI. It is also known as guanxi from the Chinese perspective, in which it refers to the exchanges of favors that dominate business activity, where contract is enforced partly by an informal social relationship (Chow, 1997). Quoting Jacob (1980; cited in Xin and Pearce 1996), guanxi can be made closer either by a social interaction that contributes to positive affect (ganqing), or by helping, in which both rely on gift giving as an indication of goodwill and respect. Since the principle of fairness or equal opportunity has been violated in the guanxi way of business conduct, Westerner threats this type of business conduct as unethical or corruption (Lovett, Simmons \& Kali, 1999). On the other hand, guanxi type of business conduct could enhance the relation and trust of involved parties. Through the trust built up by both parties, it could help to reduce the risk and afford better business control. Perhaps from the macroeconomic point of view, guanxi between countries, or we shall known it as international relations, could lead to economic growth as well as encouraging inward of FDI from good-relationship or "friendly" countries. In addition, international relations could help to reduce adverse selection, in which it allows investors to better distinguish between good and bad investments. This can lead to higher expected revenues for the foreign investors and also increase the confidence of the investors toward the countries. International relations could be developed through visits by government authorities, policies, economic relations, political relations and other means. Besides, the important of international relations has been consistent with French philosopher, Pierre Bourdieu's conceptualization of "social capital". His social capital concept mainly refers to connections within and between social networks as well as connections among individuals, which coincidently similar to the conceptual of "relationship networking" or "guanxi" of the Oriental (Har, Lam \& Liew 2009). Distinguish example is the Chinese "Bamboo network".

Nonetheless, international relations was encrypted as endogenous variable in determining effect on FDI, thus its important is not analyzed explicitly as an exogenous factor. Hence, the paper aims to (i) examine the presence of long run relationship between Malaysia's total GDP and inflow of FDI from selected countries (classified as "Model 1") as well as the long run relationship between Malaysia's total FDI and inflow of FDI from selected 
countries ("Model 2) after taking into account the effect of international relations, (ii) indentify the effect of international relations, and (iii) examine the existence of structural change before and after the significant event happened on the particular country.

\section{Literature Review}

\subsection{Review on FDI and GDP}

The results of FDI effects on economic growth have been inconclusive and still the subject of extensive public debate. The importance of FDI on economic growth had drawn attention of economists and researchers, prompting various papers to be carried out to investigate the effect of FDI on economic growth ( $\mathrm{Li} \& \mathrm{Liu}, 2004$; Marwah \& Tavakoli, 2004) and to find causality relationship between FDI and economic growth (Chakraborty \& Basu, 2001; Gao, 2004; Chowdhury \& Mavrotas, 2006; Hansen \& Rand, 2006; Hsiao \& Hsiao, 2006; Chakraborty \& Nunnenkamp, 2008; Frimpong \& Abayie, 2008).

Few papers stated that there are bidirectional effect between FDI and economic growth, in which FDI can affect economic growth and economic growth also can affect FDI (Chakraborty \& Nunnenkamp, 2008; Hsiao \& Hsiao, 2006; Choe, 2003; Chakraborty \& Basu, 2001). Both Li and Liu (2004) and Hansen and Rand (2006) claimed that it is possible that FDI not only has positive effect on economic growth but also negative effect. Chowdhury and Mavrotas (2006) found that it is GDP that causes FDI in Chile and not vice versa; simultaneously a bidirectional causality between GDP and FDI in the case of both Malaysia and Thailand. On the contrary, Gao (2004) and Carkovic and Levine (2002) pointed out that there is no direct causal relation between FDI and economic growth. Frimpong and Abayie's (2006) study on Ghana found no causality between FDI and growth for the overall and pre-structural adjustment program (pre-SAP) period yet FDI caused GDP growth during the post -SAP period. Marwah and Tavakoli (2004) explained that FDI have positive contribution. Other contribution from FDI includes playing an important role as one of the major external sources of financing (Arif, 2007), foster technological progress in the host country (Neuhaus, 2006) and develop human capital resources by getting their employees to receive training (EconomyWatch, n.d. (a)). Other empirical results that support positive relationship between FDI and economic growth include Balasubramanyam et al (1996), Olofsdotter (1998), Borensztein et.al (1998) and Bengoa and Sanchez-Robles (2003). Zhang (2001) found that growth is enhanced by FDI.

Meanwhile, the negative effect of FDI is due to the crowding out of domestic capital or development of enclave economies (Hsiao \& Hsiao, 2006). FDI also have negative effect on GDP via its interaction with technology gap, in which a large technology gap will tend to slow down the economic growth (Li \& Liu, 2004). Gao (2004) however suggests both inward FDI and economic growth respond endogenously to economic integration, as economic integration gives rise to FDI, leads to expansion of research and development (R\&D) activity in the industrial core, and increases the world growth rate. Besides, FDI itself is influenced by some other factors such as changes in technology, trade and investment policies, and changes in capital markets (Graham \& Spaulding, 2004), natural resources and cheap labour force, infrastructural factors like telecommunications and railways (EconomyWatch, n.d. (b)) as well as stable macroeconomic environment (Neuhaus, 2006).

\subsection{Reviews on International Relations (Guanxi) with GDP and FDI}

International relation, which is seen as guanxi at international level is believed to contribute to the economic growth. In fact, guanxi is an inseparable part of the Chinese business environment, which is fundamental to permeate into the Chinese societies (Buckley, Clegg, \& Tan, 2006), yet it could be viewed differently between Eastern and Western perspective. Although the influence of Chinese and phenomenon of guanxi are expanding throughout East Asia with the increasing economic importance of China, yet it remains argumentative of how guanxi affect firm's performance and what is the importance of guanxi (Park \& Luo, 2001; Xin \& Pearce, 1996; Buckley, Clegg, \& Tan, 2006). Various researches also argued on how transnational operations are accomplished through networks of personal and business relationships (Yeung, 1997; Goldberg, Heinkel \& Levi, 2005). Then again, both Western business practice and guanxi-type system, which are different types of business approach are believed to have different impact on the economic growth (Lovett, Simmons \& Kali, 1999). Lovett, Simmons and Kali (1999) evaluate guanxi from an ethical perspective and point out similarities between the ancient system of guanxi and emerging Western business practices.

Since guanxi refers to Chinese system of doing business on the basis of relationship, papers regarding guanxi are mostly based on China and evaluate through firms level. For example, Buckley, Clegg and Tan (2006) studied four firms, Park and Luo (2001) studied 128 firms across various industries in China, whereas Xin and Pearce (1996) studied 32 firms, in which firms are being categorized into three types, "state-owned", "privately owned" 
and "collective hybrids", using data based on 1992. Similarly, Yeung (1997) studied 111 headquarters and 63 subsidiaries of Hong Kong transnational corporations (TNCs) operating in the ASEAN region, in which these corporations are specified into three dimensions, "extrafirm", "interfirm", and "intrafirm". Guanxi also can be evaluated through the labor force involved in firm production (Lovett, Simmons \& Kali, 1999). While most focused on China, Goldberg, Heinkel and Levi (2005) studied impact of human interaction with FDI, focusing on US, based on FDI data in 1999 and variables such as average travel from 1996 to 1999, common language and distance.

Anyway, a closer relationship between firms can leads to better firm performance and economic growth. Yeung (1997) also explained that the role of guanxi, or personal relationships in social and business networks, is not only crucial in stimulating economic growth but also spearheading foreign direct investment (FDI) from Hong Kong TNCs (HKTNCs) into the ASEAN region. This is supported by Goldberg, Heinkel and Levi (2005), who said that human interaction can increased inward FDI. Thus, it is possible that with the international relations, it could increase GDP and FDI of one country.

Findings indicated that guanxi can contribute to firm growth through market expansion and helps firm to position itself more competitively in the market (Park \& Luo, 2001). It is viewed as more important for private companies compare to other types of organization, to compensate for the lack of formal institutional support (Xin \& Pearce, 1996). Good guanxi with the government authorities create favorable operating environment by avoiding excessive government inference (Buckley, Clegg, \& Tan, 2006). Anyway, increased international relations can increase inward FDI from one country to another country (Goldberg, Heinkel \& Levi, 2005; Yeung, 1997). Due to the increasing influence of China, guanxi-type system may be adapted by Western countries in the future, and a convergence may result from both Western and Eastern system, whereby each incorporates in the most effective aspect of the other (Lovett, Simmons \& Kali, 1999).

\section{Data and Methodology}

In this paper, the Malaysia's total FDI, total GDP and international relations are the focus of study. The annual data of FDI inflow to Malaysia range from year 1972 to 2007 for selected countries (Japan, United States, Singapore and Germany). There are total of 36 observations for each country. The data for inflow of FDI from Japan, United States, Singapore and Germany were obtained from Malaysian Development Authority (MIDA) mainly from their Annual Reports and special requests. The data for GDP was obtained from International Monetary Fund (IMF) for Malaysia, Japan, United States, Singapore, and Germany.

Two models will be created to in which these models are taking into account the effect of international relations. The first model is the relationship between inward FDI from selected four countries (Japan, U.S., Singapore and Germany) and Malaysia's total GDP, namely Model 1. The second model is relationship between inward FDI from selected countries (Japan, U.S., Singapore and Germany) and Malaysia's total FDI, namely Model 2. Thus, the dependent variables for Model 1 and Model 2 are Malaysia's total GDP and Malaysia's total FDI respectively with independent variables of the inflow of FDI from selected countries.

\subsection{Unit Root Test}

Unit root treatment of the data series is undertaken to establish their order of integration. The central idea behind this exercise is to ascertain whether, in the presence of structural breaks in the data, the series are integrated of order one or otherwise (Narayan, 2005). One of the main concerns in this paper is with the implication of structural breaks on unit roots. Given that DF and ADF test do not take into account the impact of structural breaks so we applied Perron test to examine the stationary for structural change of the time series. In order to entertain various hypotheses concerning the effect of international relations in Malaysia, consider the regression equation (see Enders, 2004):

$$
y_{t}=a_{0}+\mu_{1} D_{L}+\mu_{2} D_{p}+a_{2} t+a_{1} y_{t-1}+\sum_{i=1}^{k} \beta_{i} \Delta y_{t-i}+\varepsilon_{t}
$$

$y_{t}=$ natural base of the logarithmic of Malaysia's total GDP in year $t$ for Model 1 and natural base of the

logarithmic of Malaysia's total FDI in year $\mathrm{t}$ for Model 2 
$y_{t-1}=$ the natural base of the logarithmic of Malaysia's total GDP in year $\mathrm{t}$ in lagged one year for Model $1 \&$ the natural base of the logarithmic of Malaysia's total FDI in year $t$ in lagged one year for Model 2

$D_{p}$ (The year of the structural break $)=1$ and zero otherwise

$D_{L}=1$ for all $t$ beginning in the year of structural break and zero otherwise

The year of structural break for selected countries as shown below:

\begin{tabular}{|l|l|}
\hline Country & Year of structural break \\
\hline Japan & 1982 (Look East Policy) \\
\hline United States & 1998 (Controversial sacking of Anwar Ibrahim) \\
\hline Singapore & 1981 (Mahathir became Prime Minister) \\
\hline Germany & 1981 (Mahathir became Prime Minister) \\
\hline
\end{tabular}

Under the null hypothesis of a one-time change in the level of a unit root process, $a_{1}=1, a_{2}=0$, and $\mu_{2} \neq 0$.

Under the alternative hypothesis of a permanent one-time break in the trend stationary model, $a_{1}<1$ and $\mu_{1} \neq 0$. Lag lengths (i.e., the values of $\mathrm{k}$ ) were determined using t-tests on the coefficients $\beta_{i}$. The value $\mathrm{k}$ was selected if the t-statistic on $\beta_{k}$ was greater than 1.60 in absolute value and the $\mathrm{t}$-statistic on $\beta_{i}$ for $i>\mathrm{k}$ was less than 1.60 (Enders, 2004).

The parameter that we are interested in the regression equation 3.7 is $a_{1}, a_{2}$ and $\mu_{1}$. We will use p-value to decide whether the null hypothesis will be rejected or not in which it is automatically generated by E-views. As the alternative hypothesis is state $a_{1}<1, a_{2} \neq 0$ and $\mu_{1} \neq 0$, null hypothesis will be rejected if $\mathrm{p}$-value is less than $1 \%, 5 \%$ or $10 \%$. However, based on the alternative hypothesis for $a_{1}$, it is a one-tail test for this particular parameter. Along with this, its p-value which automatically generated by E-views will be divided by two.

First, the Perron test will be performed with the level form of the series and if the series is not stationary, we will continue the test with first differences of the series. All the t-statistics and p-values for the parameters $\left(a_{1}, a_{2}\right.$, $a_{0}, \mu_{1}$ and $\mu_{2}$ ) will be presented in the parentheses and brackets in the result Table 4.2, 4.3 and 4.4. If the null hypothesis is rejected, saying that the series is trend stationary with a structural break in the trend function. If the Perron test's result shows non-stationary at the level form of the series, cointegration test will be used to prove that there is long run relationship between the variables and thus spurious relationship can be avoided. 


\subsection{Engle-Granger Test}

The cointegration test on the variables will be performed by using the Engle-Granger approach. If the series is non-stationary, we will run the following equations for all the selected countries respectively by using OLS method:

$$
\begin{array}{lll}
Y_{t}=\beta_{0}+\beta_{1} D_{t}+\beta_{2} X_{t}+\beta_{3}\left(D_{t} X_{t}\right)+v_{t} & \text { (Model 1) } \\
Y_{t}=\alpha_{0}+\alpha_{1} D_{t}+\alpha_{2} X_{t}+\alpha_{3}\left(D_{t} X_{t}\right)+\mu_{t} & \text { (Model 2) }
\end{array}
$$

In order to determine whether the variables are cointegrated, denote the residual from the equations above by $v_{\mathrm{t}}$ and $\mu_{t}$.The $\nu_{\mathrm{t}}$ and $\mu_{t}$ series are the estimated values of the deviations from the long run relationship. It followed by 2 regressions is estimated by using the ADF test:

$$
\begin{aligned}
\Delta v_{t} & =\lambda_{1} v_{t-1}+\varepsilon_{1 t} \\
\Delta \mu_{t} & =\lambda_{2} \mu_{t-1}+\varepsilon_{2 t} \quad(\text { Model 1) }
\end{aligned}
$$

$\lambda_{1}$ and $\lambda_{2}$ are the parameters of the lagged one of the error term, and $\varepsilon_{1 t}$ and $\varepsilon_{2 t}$ are the white-noise disturbances. The null hypothesis is $\lambda_{i}=0$, represent there is no cointegration between variables, while alternative hypothesis is $\lambda_{i}=1$, representing there is a cointegration between variables and $i=1,2$. The null hypothesis will be rejected when the test statistic is greater than critical value, saying that a stationary combination of the nonstationary variables has been found and thus the variables are cointegrated. In other words, long run relationship exists between variables and hence the variables will meet in one point no matter how they veer from the long run path in the short run.

\subsection{Error Correction Mechanism (ECM)}

If the variables are cointegrated, the following process involve forming the ECM which in the context of Malaysia's total GDP and inward FDI from different countries to Malaysia as well as Malaysia's total FDI and inward FDI from different countries to Malaysia. This could be form an equation as follow:

$$
\Delta Y_{t}=\pi_{0}+\delta_{1} E C M_{t-1}+\pi_{i} \sum_{i=1}^{k} \Delta Y_{t-i}+\gamma_{i} \sum_{i=1}^{k} \Delta X_{t-i}+\varphi_{t}
$$

Where $\Delta$ denotes as the first difference operator, $\Delta Y_{t-i}$ is changes of the lagged value of Malaysia's total GDP and also changes of the lagged value of Malaysia's total FDI, $\delta_{1}$ is considered as the speed of adjustment coefficients, $E C M_{z-1}$ is the lagged one of the error from the cointegrating regression, $\Delta X_{t-i}$ is changes of lagged value of the inflow of FDI from different countries to Malaysia, $\varphi_{t}$ is white-noise disturbances, and $\mathrm{i}=1$, $2,3 \ldots$

\subsection{Analysis of Covariance (ANCOVA)}

International relations will be treated as dummy variable in order to examine its effect on the relationship between the inward FDI from selected countries and Malaysia's total GDP as well as on the relationship between inward FDI from selected countries and Malaysia's total FDI. In order to examine the effect of international relations, two models are created.

\section{Model 1:}

To examine the effect of international relations on the relationship between inward FDI from selected countries and Malaysia's total GDP, an ANCOVA model will be created as shown below: 


$$
Y_{t}=\beta_{0}+\beta_{1} D_{t}+\beta_{2} X_{t}+\beta_{3}\left(D_{t} X_{t}\right)+v_{t}
$$

Where:

$Y_{t}=$ natural base of the logarithmic of Malaysia's total GDP in year t

$D_{t}=$ Dummy variable of international relationship in lagged one year for US, Singapore and Germany and lagged two years for Japan. ( 1 if there is international relationship, 0 otherwise)

$X_{t}=$ natural base of the logarithmic of selected countries FDI which inflows to Malaysia in year $\mathrm{t}$

With assumption of homoscedasticity, two equations can be derived from ANCOVA model (refer to equation 3.13). The first equation is the mean of Malaysia's total GDP function for first period while the second equation is the mean of Malaysia's total GDP function for second period as shown below:

$$
\text { Equation 1: } \mathrm{E}\left(Y_{t} \mid D_{t}\right)=\beta_{0}+\beta_{2} X_{t}
$$

Equation 2: $\mathrm{E}\left(Y_{t} \mid D_{t}=1, X_{t}\right)=\left(\beta_{0}+\beta_{1}\right)+\left(\beta_{2}+\beta_{3}\right) X_{t}$

\section{Model 2:}

To detect the presence of structural change on the relationship between selected country's FDI and Malaysia's total FDI, an ANCOVA model will be created as shown below:

$$
Y_{t}=\alpha_{0}+\alpha_{1} D_{t}+\alpha_{2} X_{t}+\alpha_{3}\left(D_{t} X_{t}\right)+\mu_{t}
$$

Where:

$Y_{t}=$ natural base of the logarithmic of Malaysia's total FDI in year $\mathrm{t}$

$D_{t}=$ Dummy variable of international relationship in lagged one year for US, Singapore and Germany and lagged two years for Japan. (1 if there is international relationship, 0 otherwise)

$X_{t}=$ natural base of the logarithmic of selected countries FDI which inflows to Malaysia in year $\mathrm{t}$

With assumption of homoscedasticity, two equations can be derived from ANCOVA model (refer to equation 3.16). The first equation is the mean of Malaysia's total FDI function for first period while the second equation is the mean of Malaysia's total FDI function for second period as shown below:

Equation 1: $\mathrm{E}\left(Y_{t} \mid D_{t}\right)=\alpha_{0}+\alpha_{2} X_{t}$

Equation 2: E $\left(Y_{t} \mid D_{t}=1, X_{t}\right)=\left(\alpha_{0}+\alpha_{1}\right)+\left(\alpha_{2}+\alpha_{3}\right) X_{t}$ 


\subsection{Chow Test}

The idea behind the Chow test is that if in fact there is no structural change then the $R S S_{R}$ and $R S S_{U R}$ should not be statistically different. Hence, the statistical formula for Chow test is shown as below:

$$
F=\frac{\left(R S S_{R}-R S S_{U R}\right) / k}{\left(R S S_{U R}\right) /\left(n_{1}+n_{2}-2 k\right)}
$$

Hence, we reject null hypothesis when the estimated value is significant at $1 \%, 5 \%$ or $10 \%$ and saying that there is structural change on the relationship between Malaysia's total GDP and inward FDI from selected countries (Model 1) as well as on the relationship between Malaysia's total FDI and inward FDI from selected countries (Model 2).

\section{Results and Interpretation}

\subsection{Unit Root Test}

Since all the series do not appeared to be significant for the three parameters $\left(a_{1}, a_{2}, \mu_{1}\right)$ simultaneously concerned, the null hypothesis is not rejected. It is concluded that all the series are non-stationary for structural break for both level form and first difference due to significant event for different countries. Hence, Engle-Granger test is carried out to test whether non-stationary variables are cointegrated or spuriously related.

\subsection{Engle-Granger Test}

All the test statistics in Model 1 and Model 2 are significant to reject the null hypothesis of no cointegration relationship between Malaysia's total GDP and FDI from selected countries (Model 1) and between Malaysia's total FDI and FDI from selected countries (Model 2). It would be concluded that a stationary combination of the non-stationary variables has been found and thus that the variables are cointegrated. In other words, there is long run relationship between the variables and so there is no spurious regression problem in both models.

\subsection{Error Correction Mechanism (ECM)}

The error correction for Model 1 is statistically significant for country of Japan, United States and Singapore except Germany. However, with all countries' ECM generated have negative signs, it is concluded that these variables have converge in the long run. In other words, Malaysia's total GDP and inward FDI from the particular country (Japan, United States, Singapore and Germany) have short run relationship in which ECM will try to reinstate the equilibrium in the case these variables veer from their long run path.

As for Model 2, the error correction is statistically significant for Singapore and Germany except Japan and United States. However, as the ECM all the countries in Model 2 have negative signs, we strongly suggesting that the variables have converged in the long run. This means there is an existence of short run relationship between Malaysia's total FDI and inward FDI from selected four countries.

\subsection{Analysis of Covariance (ANCOVA)}

\subsubsection{Model 1}

\section{$\underline{\text { Japan }}$}

Estimation model for Japan was generated as shown below:

$$
Y_{t}=20.6436-4.2411 D_{t}+0.1987 X_{t}+0.2616\left(D_{t} X_{t}\right)
$$

From (4.1), two equations can be derived which are:

GDP - FDI from Japan regression, 1972 -1981:

$$
Y_{t}=20.6436+0.1987 X_{t}
$$

GDP - FDI from Japan regression, 1982 -2007:

$$
Y_{t}=16.4025+0.4603 X_{t}
$$


Holding other variables constant, when international relations exist between Malaysia and Japan (dummy=1), Malaysia's GDP will increase more than the period without international relations exist by $0.2616 \%$ on average while Malaysia's total GDP will be lowered by 4.2411 when there is no inflow of FDI from Japan. Adjusted R ${ }^{2}$ is 0.7221 , means that $72.21 \%$ of the variation in Malaysia's total GDP can be explained by variation in international relations and inward FDI from Japan taking into account sample size and number of independent variables.

\section{$\underline{\text { United States }}$}

Estimation model for US was generated as shown below:

$$
Y_{t}=16.9286+7.8891 D_{t}+0.4170 X_{t}-0.3252\left(D_{t} X_{t}\right)
$$

From (4.4), two equations can be derived which are:

GDP - FDI from US regression, 1972 -1997:

$$
Y_{t}=16.9286+0.4170 \mathrm{X}_{\mathrm{t}}
$$

GDP - FDI from US regression, 1998 -2007:

$$
Y_{t}=24.8177+0.0918 \mathrm{X}_{\mathrm{t}}
$$

Holding other variables constant, when international relations exist between Malaysia and US (dummy=1), Malaysia's total GDP will decrease more than the period without international relations exist by $0.3252 \%$ on average and Malaysia's total GDP will be increased by 7.8891 when there is no inflow of FDI from US. Adjusted $\mathrm{R}^{2}$ is 0.8111 , means that $81.11 \%$ of the variation in Malaysia's total GDP can be explained by variation in international relations and inward FDI from US taking into account sample size and number of independent variables.

\section{$\underline{\text { Singapore }}$}

Estimation model for Singapore was generated as shown below:

$$
Y_{t}=20.5159-4.8321 D_{t}+0.1954 X_{t}+0.3137\left(D_{t} X_{t}\right)
$$

From (4.7), two equations can be derived which are:

GDP - FDI from Singapore regression, 1972 -1980:

$$
Y_{t}=20.5159+0.1954 X_{t}
$$

GDP - FDI from Singapore regression, 1981 -2007:

$$
Y_{t}=15.6839+0.5091 X_{t}
$$

Holding other variables constant, when international relations exist between Malaysia and Singapore $($ dummy $=1)$, Malaysia's total GDP will increase more than the period without international relations exist by $0.3137 \%$ on average and Malaysia's total GDP will be lowered by 4.8320 when there is no inflow of FDI from Singapore. Adjusted $\mathrm{R}^{2}$ is 0.8534 , means that $85.34 \%$ of the variation in Malaysia's total GDP can be explained by variation in international relations and inward FDI from Singapore taking into account sample size and number of independent variables.

\section{Germany}

Estimation model for Germany was generated as shown below:

$$
Y_{t}=20.6548-1.6701 D_{t}+0.2146 X_{t}+0.1546\left(D_{t} X_{t}\right)
$$

From (4.10), two equations can be derived which are:

GDP - FDI from Germany regression, 1972 -1980:

$$
Y_{t}=20.6548+0.2146 X_{t}
$$

GDP - FDI from Germany regression, 1981 -2007:

$$
Y_{t}=18.9848+0.3692 X_{t}
$$

Holding other variables constant, when international relations exist between Malaysia and Germany $($ dummy $=1)$, Malaysia's GDP will increase more than the period without international relations exist by $0.1546 \%$ on average and Malaysia's total GDP will be lowered by 1.67 when there is no inflow FDI from Germany. Adjusted R ${ }^{2}$ is 0.8766 , means that $87.66 \%$ of the variation in Malaysia's total GDP can be explained by variation in 
international relations and inward FDI from Germany taking into account sample size and number of independent variables.

Based on the estimation output, both the differential intercept, $\beta_{1}$ and slope coefficients, $\beta_{3}$ are statistically insignificant for US, strongly suggesting that there is no effect of international relations in the relationship between Malaysia's total GDP and inflow FDI from US between two periods. On the other hand, the differential intercept, $\beta_{1}$ and slope coefficients, $\beta_{3}$ are statistically significant for Japan, Singapore and Germany, strongly indicating that the effect of international relations on the relationship between Malaysia's total GDP and inflow FDI from Japan Singapore and Germany is exist.

\subsubsection{Model 2}

Japan

An estimation model for Japan was generated as shown below:

$$
Y_{t}=8.3920-5.4345 D_{t-1}+0.6461 X_{t}+0.3011\left(D_{t} X_{t}\right)
$$

From (4.13), two equations can be derived which are:

Total FDI - FDI from Japan regression, 1972 -1981:

$$
Y_{t}=8.3920+0.6461 X_{t}
$$

Total FDI - FDI from Japan regression, 1982 -2007:

$$
Y_{t}=2.9575+0.9472 X_{t}
$$

Holding other variables constant, when international relations exist between Malaysia and Japan (dummy=1), Malaysia's total FDI will increase more than the period without international relations exist by $0.3011 \%$ on average and Malaysia's total FDI will be lowered by 5.4345 if there is no inflow FDI from Japan. The adjusted $\mathrm{R}^{2}$ is 0.9211 , means that $92.11 \%$ of the variation in Malaysia's total FDI can be explained by variation in international relations and inward FDI from Japan taking into account sample size and number of independent variables.

\section{United States}

Estimation model for US was generated as shown below:

$$
Y_{t}=6.8614+4.5485 D_{t}+0.7587 X_{t}-0.2021\left(D_{t} X_{t}\right)
$$

From (4.16), two equations can be derived which are:

Total FDI - FDI from US regression, 1972 -1997:

$$
Y_{t}=6.8614+0.7587 X_{t}
$$

Total FDI - FDI from US regression, 1998 -2007:

$$
Y_{t}=11.4099+0.5566 X_{t}
$$

Holding other variables constant, when international relations exist between Malaysia and US (dummy=1), Malaysia total FDI will decrease more than the period without international relations exist by $0.2021 \%$ on average and Malaysia's total FDI will be increased by 4.5485 if there is no inflow FDI from US. The adjusted R ${ }^{2}$ is 0.8434 , means that $84.34 \%$ of the variation in Malaysia's total FDI can be explained by variation in international relations and inward FDI from US taking into account sample size and number of independent variables.

\section{$\underline{\text { Singapore }}$}

Estimation model for Singapore was generated as shown below:

$$
Y_{t}=13.7371-8.4099 D_{t}+0.3604 X_{t}+0.5004\left(D_{t} X_{t}\right)
$$

From (4.19), two equations can be derived which are:

Total FDI - FDI from Singapore regression, 1972 -1980:

$$
Y_{t}=13.7371+0.3604 X_{t}
$$


Total FDI - FDI from Singapore regression, 1981 -2007:

$$
Y_{t}=5.3272+0.8609 X_{t}
$$

Holding other variables constant, when international relations exist between Malaysia and Singapore (dummy=1), Malaysia's total FDI will increase more than the period without international relations exist by $0.5004 \%$ on average and Malaysia's total FDI will be lowered by 8.4099 if there is no inflow FDI from Singapore. The adjusted $\mathrm{R}^{2}$ is 0.9263 , means that $92.63 \%$ of the variation in Malaysia's total FDI can be explained by variation in international relations and inward FDI from Singapore taking into account sample size and number of independent variables.

Germany

Estimation model for Germany was generated as shown below:

$$
Y_{t}=15.6225-2.7830 D_{t}+0.2978 X_{t}+0.2253\left(D_{t} X_{t}\right)
$$

From (4.22), two equations can be derived which are:

Total FDI - FDI from Germany regression, 1972 -1980:

$$
Y_{t}=15.6225+0.2978 X_{t}
$$

Total FDI - FDI from Germany regression, 1981 -2007:

$$
Y_{t}=12.8396+0.5231 X_{t}
$$

Holding other variables constant, when international relations exist between Malaysia and Germany (dummy=1), Malaysia's total FDI will increase more than the period without international relations exist by $0.2253 \%$ on average and Malaysia's total FDI will be lowered by 2.7829 if there is no inflow FDI from Germany. The adjusted $\mathrm{R}^{2}$ is 0.8055 , means that $80.55 \%$ of the variation in Malaysia's total FDI can be explained by variation in international relations and inward FDI from Germany taking into account sample size and number of independent variables.

Based on the estimation output, both the differential intercept, $\alpha_{1}$ and slope coefficients, $\alpha_{3}$ are statistically insignificant for US, strongly suggesting that there is no effect of international relations on the relationship between Malaysia's total FDI and inflow FDI from US between two periods. On the other hand, the differential intercept, $\alpha_{1}$ and slope coefficients, $\alpha_{3}$ are statistically significant for Japan, Singapore and Germany, strongly indicating that the effect of international relations on the relationship between Malaysia's total FDI and inflow FDI from Singapore, Germany and Japan is exist.

\subsection{Chow Test}

\subsubsection{Model 1}

With degree of freedom of 2 and 32, the critical values are 3.32 and 5.39 at significant level of $5 \%$ and $1 \%$ respectively. As the partial F-statistic for all selected countries are greater than 5.39, we reject null hypothesis at $1 \%$ significant level. Thus, based on Chow test, the presence structural change on the relationship between Malaysia's total GDP and inward FDI from selected countries was detected after taking into account the international relations between Malaysia and the countries to be investigated (Japan, US, Singapore and Germany).

\section{Summary}

Guanxi, from a micro perspective could improve businesses; thus when implemented to a macro view, international relations also could positively affects Malaysia's GDP and FDI. Empirical studies had threat international relations as endogenous variable, which could not significantly proof that international relations contribute towards FDI and GDP.

As expected, Japan and Germany have positive impact of international relations for both models. This is because the implementation of "Look East" Policy in 1982 had encouraged more Japanese companies to invest in Malaysia. In addition, it is also expected to accelerate Malaysia's development projects through increased foreign investment, technology transfer, in house training, introduction to Eastern values, as well as the human resources development. While as for Germany, Germany and Malaysia have enjoyed close and longstanding economic ties and strong business partnership during the era of Mahathir, which is continued until now. Besides that, Germany is the largest investor in Malaysia. Investments by German companies include a new wafer factory (Infineon), new plant for manufacturing PBT, a plastic used primarily in the electrical and electronics sector and the automotive industry, as well as facilities for manufacturing metal goods and chemical products (Auswartiges Amt, 2009). 
As for United States, negative impact of international relations for both models is not surprising. This is because the controversial sacked of then Deputy Prime Minister, Anwar Ibrahim in 1998 had created a big issues not only in Malaysia itself, but also foreign countries, particularly the United States. Mahathir described United States vice president, Al Gore's rebuke comment on this case as "disrespectful" and "offensive" for interfering in Malaysian affairs (Ahmad, 2008) while blasted George Soros as "archetypal rogue currency trader" for his alleged involvement in triggering the Asian Crisis 1997/98 (Mahathir Mohamad 2000: 55). While as for Singapore, during the era of Mahathir, despite being the closest neighbor of Singapore, the relationship between both countries had been stormy due to issues such as disagreement on raw water prices and status of Pulau Batu Putih. Thus, we expected the poor international relations between both countries would worsen the relationship between Malaysia's total GDP and inward FDI, as well as relationship between Malaysia's total FDI and inward FDI. However, our results show a positive impact of international relations on both models. In which we suspect this is due to efforts and incentives by Malaysia's government to attract inward FDI. For examples, Establishment of Free Trade Zone (FTZ) facilities for export oriented industries, Promotion of Investments Act 1986, and incentives which allowed a tax relief up to 10 years, exemption from Malaysian income tax for 5 years and renewable to 10 years. Perhaps due to geography close proximity, Singapore remains an important source of investment for Malaysia.

Finally, results show that there is structural change in each country. This indicates that international relations play an important role in attracting inward FDI to our countries.

\section{References}

Ahmad, A. (2008). Dr Mahathir's Selected Letters to World Leaders. Malaysia: Marshall Cavendish Sdn. Bhd.

Arif, M. (2007). Economic Openness, Volatility \& Resilience: Malaysian Perspectives. Malaysia: Malaysian Institute of Economic Research.

Auswartiges Amt. (2009). Bilateral Relations: Malaysia. [Online] Available: http://www.auswaertiges-amt.de/diplo/en/Laenderinformationen/01-Laender/Malaysia.html (June 11, 2009).

Balasubramanyam, V. N., Salisu, M., and Sapsford, D. (1996). Foreign direct investment and growth in EP and IS countries. Economic Journal, 106, 92-105.

Bengoa, M. and Sanchez-Robles, B. (2003). Foreign direct investment, economic freedom and growth: new evidence from Latin America. European Journal of Political Economy, 19, 529 - 545.

Borensztein, E., De Gregorio, J., and Lee, J. W. (1998). How does foreign direct investment affect economic growth? Journal of International Economics, 45, 115-135.

Buckley, P.J., Clegg, J., \& Tan, H. (2006). Cultural awareness in knowledge transfer to China - The role of guanxi and mianzi. Journal of World Business, 41(2006), 275-288.

Carkovic, M. and Levine, R. (2002). Does foreign direct investment accelerate economic growth? University of Minnesota, Working Paper.

Chakraborty, C., \& Basu, P. (2001). Foreign direct investment and growth in India: a cointegration approach. Applied Economics, 34, 1061 - 1073.

Chakraborty, C., \& Nunnenkamp, P. (2008). Economic reforms, FDI, and economic growth in India: A sector level analysis. World Development, 36(7), $1192-1212$.

Choe, J.I. (2003). Do foreign direct investment and gross domestic investment promote economic growth? Review of Development Economics, 7, $44-57$.

Chow, G.C. (1997). Challenges of China's economic system for economic theory. The American Economic Review, 87(2), 321-327.

Chowdhury, A., \& Mavrotas, G. (2006). FDI and growth: What causes what? World Economy, 29(1), 9-19.

EconomyWatch (b). (n.d.). FDI: Determinants of Foreign Direct Investment. [Online] Available: http://www.economywatch.com/foreign-direct-investment/determinants.html (July 3, 2009).

EconomyWatch. (n.d. (a)). FDI: Benefits of Foreign Direct Investment. [Online] Available: http://www.economywatch.com/foreign-direct-investment/benefits.html (July 3, 2009).

Enders, W. (2004). Applied Econometric Time Series, (2 ${ }^{\text {nd }}$ ed.). Hoboken: John Willey \& Sons, Inc.

Frimpong, J.M., \& Oteng-Abayie, E.F. (2008). Bivariate causality analysis between FDI inflows and economic in Ghana. International Research Journal of Finance and Economics, 15.

Furuoka, F., Lo, M.C., \& Kato, I. (2008). Japan's Foreign Aid Policy Towards Malaysia. Case Studies of the New Miyazawa Initiative and the Kelau Dam Construction. [Online] Available: http://www.japanesestudies.org.uk/articles/2007/FuruokaLoKato.html (August 16, 2008). 
Gao, T. (2004). Foreign direct investment and growth under economic integration. Journal of International Economics, 67(2005), 157-174.

Goldberg, M.A., Heinkel, R.L., \& Levi, M.D. (2005). Foreign direct investment: The human dimension. Journal of International Money and Finance, 24(2005), 913 - 934.

Graham, J.P., \& Spaulding, R.B. (2004). Going Global: Understanding Foreign Direct Investment (FDI). [Online] Available: http://www.going-global.com/articles/understanding_foreign_direct_investment.htm (July 3, 2009).

Hansen, H., \& Rand, J. (2006). On the causal links between FDI and growth in developing countries. World Economy, 29(1), 21-41.

Har W. M., Lam Z. L. \& Liew K. Yi. (2009). Malaysia-West Asia relations and foreign direct investment: Proposal for an Ummah Network based on social capital concept. Journal of International Social Research. Vol. 2, (6): $434-445$.

Hsiao, F.S.T., \& Hsiao, M.C.W. (2006). FDI, exports, and GDP in East and Southeast Asia: Panel data versus time-series causality analyses. Journal of Asian Economies, 17, $1082-1106$.

Li, X., \& Liu, X. (2004). Foreign direct investment and economic growth: An increasingly endogenous relationship. World Development, 33(3), $393-407$.

Lim, G.E. (2006). Tun Mahathir is right that the country's economy is bad when for the first time in history. [Online] Available: http://dapmalaysia.org/english/2006/oct06/lge/lge490.htm (August 16, 2008).

Lovett, S., Simmons, L.C., \& Kali, R. (1999). Guanxi versus the market: Ethnics and efficiency. Journal of International Business Studies, 30(2), $231-247$.

Mahathir Mohamad. (2000). The Malaysian Currency Crisis: How and why it Happened. Kuala Lumpur: Pelanduk.

Malaysia Daily News. (2009). Asean Affairs: Malaysia FDI plunges in Jan-May 2009. [Online] Available: http://www.aseanaffairs.com/malaysia_daily_news_updates/investment/malaysia_fdi_plunges_in_jan_may_200 9 (August 1, 2009).

Marwah, K., \& Tavakoli, A. (2004). The effect of foreign capital and imports on economic growth: Further evidence from four Asian countries (1970-1998). Journal of Asian Economics, 15(2004), 399 - 413.

Narayan, P. K. (2005). The Saving and Investment nexus for China: Evidence from cointegration test. Journal of Applied Econometrics, 37(2005), 1979-1990.

Neuhaus, M. (2006). The Impact of FDI on Economic Growth: An analysis for the transition countries of Central and Eastern Europe. Germany: Physica - Verlag.

Olofsdotter, K. (1998). Foreign direct invest, country capabilities and economic growth. Review of World Economics, 134(3), $534-547$.

Park, S.H., \& Luo, Y. (2001). Guanxi and organizational dynamics: Organizational networking in Chinese firms. Strategic Management Journal, 22, 455 - 477.

Xin, K.R., \& Pearce, J.L. (1996). Guanxi: Connections as substitutes for formal institutional support. Academy of Management Journal, 39(6), 1641 - 1658.

Yeung, H.W.C. (1997). Business networks and transnational corporations: A study of Hong Kong firms in the Asean Region. Economic Geography, 73(1), 1-25.

Zhang, K.H. (2001). Does foreign direct investment promote economic growth? Evidence from East Asia and Latin America. Contemporary Economic Policy, 19(2), 175-185.

Table 1. Result of Perron test on Malaysia's GDP

\begin{tabular}{lccccc}
\hline & $a_{0}$ & $\mu_{1}$ & $\mu_{2}$ & $a_{2}$ & $a_{1}$ \\
\hline Japan & & & & & \\
Level & 45.6807 & 0.1364 & -0.0793 & 0.1944 & -0.9666 \\
& $(3.9473)$ & $(1.6282)$ & $(-1.0496)$ & & $(-1.9310)^{* *}$ \\
& & & & $(3.2911)^{* * *}$ & \\
\hline
\end{tabular}




\begin{tabular}{lccccc}
\hline \multicolumn{1}{c}{ Level } & 31.1490 & -0.0324 & -0.0094 & 0.1344 & -0.3357 \\
& $(2.8159)$ & $(-0.7017)$ & $(-0.1605)$ & $(2.8587)^{* *}$ & $(-0.7055)$ \\
\multicolumn{1}{c}{ First difference } & 0.0999 & -0.0497 & -0.0606 & 0.0027 & -0.4657 \\
& $(0.9878)$ & $(-0.8991)$ & $(-0.9068)$ & $(0.7495)$ & $(-0.8491)$ \\
\hline Singapore & & & & & \\
Level & 30.0662 & -0.0797 & -0.0528 & 0.1273 & -0.2896 \\
& $(3.6988)$ & $(-0.8321)$ & $(-0.7288)$ & & $(-0.8247)$ \\
First difference & 0.2155 & -0.0797 & 0.0019 & $3.38 \mathrm{E}-06$ & -0.4101 \\
& $(1.6823)$ & $(-0.8321)$ & $(0.0199)$ & $(0.0019)$ & $(-0.7736)$ \\
\hline Germany & & & & & \\
Level & 30.0662 & -0.0797 & -0.0528 & 0.1273 & -0.2896 \\
& $(3.6988)$ & $(-0.8321)$ & $(-0.7288)$ & $(3.6699)^{* * *}$ & $(-0.8247)$ \\
First difference & 0.2155 & -0.0797 & 0.0019 & $3.38 \mathrm{E}-06$ & -0.4101 \\
& $(1.6823)$ & $(-0.8321)$ & $(0.0199)$ & $(0.0019)$ & $(-0.7736)$ \\
\hline
\end{tabular}

Notes: ${ }^{* *},{ }^{* *}, *$ indicates the rejection of the null hypothesis at $1 \%, 5 \%$, and $10 \%$ significance levels. The appropriate t-statistics are in parentheses.

Table 2. Result of Perron test on Malaysia total FDI

\begin{tabular}{lccccc}
\hline & $a_{0}$ & $\mu_{1}$ & $\mu_{2}$ & $a_{2}$ & $a_{1}$ \\
\hline Japan & & & & \\
Level & 9.8972 & -0.4209 & 0.2305 & 0.0658 & 0.5134 \\
\hline United & $(1.3906)$ & $(-0.7115)$ & $(0.3868)$ & $(1.1739)$ & $(1.3637)^{*}$ \\
States & 4.6907 & -1.3624 & 0.1195 & 0.0942 & 0.7355 \\
Level & $(0.6440)$ & $(-2.2577)^{* *}$ & $(0.1804)$ & $(1.6249)$ & $(1.9180)^{* *}$ \\
\hline Singapore & & & & & \\
Level & 9.7185 & 0.4821 & 0.4060 & 0.0694 & 0.4765 \\
& $(1.6426)$ & $(0.8972)$ & $(0.7401)$ & $(1.5425)$ & $(1.5449)^{*}$ \\
\hline Germany & & & & \\
Level & 9.7185 & 0.4821 & 0.4060 & 0.0694 & 0.4765 \\
\hline
\end{tabular}

Notes: $* * *, * * *$ indicates the rejection of the null hypothesis at $1 \%, 5 \%$, and $10 \%$ significance levels. The appropriate t-statistics are in parentheses.

Table 3. Result of Engle-Granger Test for Model 1 and Model 2

\begin{tabular}{lcc}
\hline & Test Statistic for Model 1 & Test Statistic for Model 2 \\
\hline Countries & $-2.4807^{* * *}$ & $-2.4919^{* *}$ \\
Japan & $-2.8252^{* * *}$ & $-3.6248^{* * *}$ \\
United States & $-1.8219^{*}$ & $-4.0108^{* * *}$ \\
Singapore & $-3.7277^{* * *}$ & $-3.0739^{* * *}$ \\
Germany &
\end{tabular}

Notes: $* * *, * *, *$ indicates the rejection of the null hypothesis at $1 \%, 5 \%$, and $10 \%$ significance levels. 
Table 4. Result of ECM for Model 1 and Model 2

\begin{tabular}{|l|ll|}
\hline Countries & $E C M_{t-1}$ for Model 1 & $E C M_{t-1}$ for Model 2 \\
\hline Japan & $-0.0439^{* *}$ & -0.2052 \\
United States & $-0.0775^{* *}$ & -0.0198 \\
Singapore & $-0.0841^{* *}$ & $-0.5462^{* * *}$ \\
Germany & -0.0434 & $-0.3185^{* *}$ \\
\hline
\end{tabular}

Notes: ${ }^{* * *},{ }^{* *},{ }^{*}$ indicates the rejection of the null hypothesis at $1 \%, 5 \%$, and $10 \%$ significance levels

Table 5. The regression result of Model 1

\begin{tabular}{lllll}
\hline & Japan & United States & Singapore & Germany \\
\hline $\mathrm{C}$ & $20.6436^{*}$ & $16.9286^{* * *}$ & $20.5159^{* * *}$ & $20.5744^{* * *}$ \\
& $(9.0918)$ & $(1.1591)$ & $(2.1664)$ & $(0.6984)$ \\
\hline$D^{i}{ }_{t}$ & $-4.2411^{* * *}$ & 7.8891 & $-4.8321^{* *}$ & $-1.6701^{*}$ \\
& $(-1.8550)$ & $(5.6641)$ & $(2.1702)$ & $(0.8261)$ \\
\hline$X^{i}{ }_{t}$ & 0.1987 & $0.4170^{* * *}$ & $0.1954^{*}$ & $0.2146^{* * *}$ \\
& $(1.6664)$ & $(0.0590)$ & $(0.1140)$ & $(5.1840)$ \\
\hline$D^{i}{ }_{t} X^{i}{ }_{t}$ & $0.2616^{* *}$ & -0.3252 & $0.3137^{* * *}$ & $0.1546^{* * *}$ \\
& $(2.2705)$ & $(0.2581)$ & $(0.1136)$ & $(3.3722)$ \\
\hline Adjusted ${ }^{2}$ & 0.7221 & 0.8111 & 0.8534 & 0.8766
\end{tabular}

Note: $* * * * * *$ denotes significant level at 1 percent, 5 percent, and 10 percent respectively. The standard errors are in parentheses.

Table 6. The regression result for Model 2

\begin{tabular}{lllll}
\hline & Japan & United States & Singapore & Germany \\
\hline $\mathrm{C}$ & $8.3920^{*}$ & $6.8614^{* * *}$ & $13.7371^{* * *}$ & $15.6225^{* * *}$ \\
& $(5.0603)$ & $(1.4099)$ & $(2.0781)$ & $(1.1861)$ \\
\hline$D^{l}{ }_{t}$ & $-5.4345^{*}$ & 4.5485 & $-8.4099^{* * *}$ & $-2.7830^{*}$ \\
& $(-3.2544)$ & $(6.8896)$ & $(2.0819)$ & $(1.4030)$ \\
\hline$X^{i}{ }_{t}$ & $0.6461^{*}$ & $0.7587^{* * *}$ & $0.3604^{* * *}$ & $0.2978^{* * *}$ \\
& $(7.4190)$ & $(0.0717)$ & $(0.1094)$ & $(0.0703)$ \\
\hline$D^{i}{ }_{t} X^{i}{ }_{t}$ & $0.3011^{*}$ & -0.2021 & $0.5004^{* * *}$ & $0.2253^{* * *}$ \\
& $(3.5777)$ & $(0.3139)$ & $(0.1090)$ & $(0.0779)$ \\
\hline Adjusted & 0.9211 & 0.8434 & 0.9263 & 0.8055 \\
$\mathrm{R}^{2}{ }^{2}$ & & & &
\end{tabular}

Note: $* * * * * *$ denotes significant level at 1 percent, 5 percent, and 10 percent respectively. The standard errors are in parentheses.

Table 7. Result of Chow Test for Model 1

\begin{tabular}{lccccc}
\hline & $R S S_{R}$ & $R S S_{1}$ & $R S S_{2}$ & $R S S_{U R}$ & Partial F-statistic \\
\hline Japan & 12.6249 & 1.2048 & 6.7040 & 7.9088 & $9.5410^{* * *}$ \\
\hline $\begin{array}{l}\text { United } \\
\text { States }\end{array}$ & 10.3423 & 6.5740 & 0.3030 & 6.8770 & $8.0624^{* * *}$ \\
\hline Singapore & 14.2368 & 1.3527 & 3.3390 & 4.6917 & $32.5514^{* * *}$ \\
\hline Germany & 11.1207 & 0.1625 & 3.7645 & 3.9270 & $29.3097^{* * *}$ \\
\hline
\end{tabular}

Note: ***,**,* denotes significant level at 1 percent, 5 percent, and 10 percent respectively. 